\title{
THUMBS, FINGERS, AND PUSHING ON STRING: LEGAL ACCOUNTABILITY IN THE USE OF FEDERAL FINANCIAL INCENTIVES
}

\author{
KERNAGHAN WEBB
}

The federal government makes extensive use of its spending powers to establish programs intended to influence private behaviour in furtherance of public policy objectives. Incentives are frequently used where more conventional policy instruments would not be appropriate or available. However, in many situations, such programs lack adequate legal structure. The author concludes that the minimal legal structure allows for tremendous administrative flexibility. but detracts from effective accountability: and can negatively affect operational fairness. Taking a functional approach to analysis, the author argues that since incentives are public policy instruments intended to alter behaviour, they are akin (though not identical) to conventional regulatory approaches, and so should be subject to many of the same legal principles and structures as apply to conventional policy instruments. The effect would be more open and accountable frameworks for the creation and operation of incentives, which should result in better designed and more fair and efficiently functioning incentive regimes.

\section{TABLE OF CONTENTS}

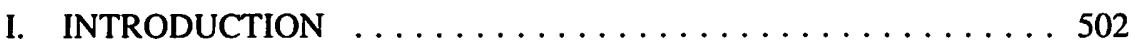

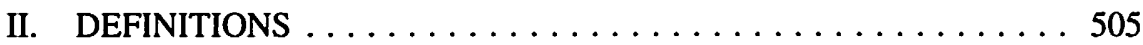

III. THE NEED FOR BETTER LEGAL ACCOUNTABILITY . . . . . . . . . . . . . . . . . . 509

IV. ACCOUNTABILITY IN INCENTIVE

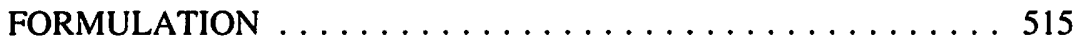

A. INCENTIVES AND THE DIVISION
OF POWERS $\ldots \ldots \ldots \ldots \ldots \ldots \ldots \ldots \ldots \ldots \ldots \ldots \ldots \ldots \ldots \ldots$

B. LEGISLATIVE ELABORATION OF

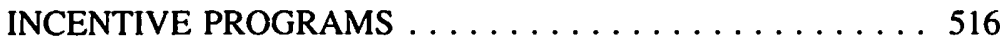

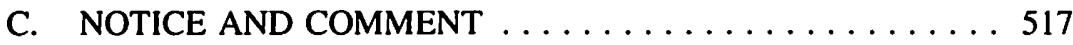

D. ADMINISTRATIVE ELABORATION OF INCENTIVE PROGRAMS . . . . . . . . . . . . . 519

V. ACCOUNTABILITY IN INCENTIVE ADMINISTRATION AND ENFORCEMENT $\ldots \ldots \ldots \ldots \ldots 521$

A. REASONABLENESS IN INCENTIVE ADMINISTRATION $\ldots \ldots \ldots \ldots \ldots \ldots \ldots 21$

B. PROCEDURAL FAIRNESS IN INCENTIVE ADMINISTRATION $\ldots \ldots \ldots \ldots \ldots \ldots .523$

C. THE CHARTER AND INCENTIVE ADMINISTRATION $\ldots \ldots \ldots \ldots \ldots \ldots \ldots 530$

Consumer Affairs Bureau, Consumer and Corporate Affairs Canada; Sessional Lecturer, Faculty of Law. University of Ottawa. At the time of writing, the author was a consultant to the Administrative Law Project, Law Reform Commission of Canada. The article represents the opinions of the author, and not those of the Law Reform Commission of Canada or the Government of Canada. The author is grateful to the many persons who provided comments on earlier drafts, and in particular to John Frecker, Law Reform Commission of Canada, and Professor Ellen Baar, York University. 


\section{THIRD PARTIES AND ENFORCEMENT}

UNEXPLORED TERRITORY $\ldots \ldots \ldots \ldots \ldots \ldots \ldots 531$

VI. CONCLUSIONS ........................ 533

\section{INTRODUCTION}

An economist once characterized authority systems as having "strong thumbs, [but] no fingers." In some ways, this comment is apt to describe the situation in Canada with respect to use of incentives and their legal accountability. First, it reflects the preoccupation of many with the "thumbs" of government - i.e., the classic coercive ${ }^{2}$ tools such as command-penalty offences, taxes and expropriations * which, because they represent overt manifestations of the State's power to deprive individuals of their life, liberty, security or property, dominate the attention of many legal, political and economic commentators. There is no doubt of the importance of these instruments, and no doubt that their use needs to be thoroughly circumscribed by political, legal and administrative frameworks. To put it bluntly, the use of the State's coercive powers necessitates equally sturdy and thumblike accountability mechanisms: thus, traditional regulatory regimes ${ }^{3}$ are typically subject to (among others) division of powers constitutional constraints, ${ }^{4}$ notice and comment requirements, ${ }^{5}$ and Charter $^{6}$ principles of fundamental justice.

At the same time, Canadian governments make use of many financial incentives to encourage private sector compliance with public policies. As used here, incentives qualify as examples of the State's "fingers." Contrary to the impression given by the strongthumbs-no-fingers aphorism, the position taken here is that in fact there are many fingers being used by the federal government, but often they operate outside of the glare of public scrutiny and effective control. Fingers can be less clumsy than thumbs, and are capable

C. Lindblom, Politics and Markets: The World's Political-economic Systems (New York: Basic Books, 1977) at 65.

2 Coercion has been defined in J. Gould \& W. Kolb, eds., Dictionary of the Social Sciences (New York: Macmillan, 1964) at 98 as follows:

Coercion signifies, in general, the imposition of external regulation and control upon persons, by threat or use of force and power.

Whether or not spending programs designed to influence private sector behaviour can be described as coercive is an interesting question, deserving of more detailed examination than is possible in this article. For present purposes, it is accepted without further comment that coercion implies the threat of negative sanctions. Later in the article it will be seen that an incentive regime can include what are arguably coercive components (eg., the threat of loss of opportunity to do business with the federal government). In this paper, the term "traditional regulatory regimes" or "traditional regulatory instruments" will be taken to include regulatory offences and licences. A regulatory instrument is one which is intended to influence private sector behaviour.

4 E.g., the legislative division of powers set out primarily in ss. 91 and 92 of the Constitution Act, 1867 (U.K.), 30 \& 31 Vict., c. 3.

5 E.g., through the Canada Gazette, and as part of the federal Regulatory Plan.

- Constitution Act, 1982, being Schedule B to the Canada Act 1982 (U.K.), 1982, c. 11.

7 E.g., s. 7 constraints on the ability of governments to impose the penalty of imprisonment in the absence of fault, as per Reference re S. 94(2) of the Motor Vehicle Act (B.C.), [1985] 2 S.C.R. 486. 
of probing where thumbs cannot go - for example, the federal government $\operatorname{can}^{8}$ and has created many incentive programs which directly affect matters of provincial legislative jurisdiction ${ }^{9}$ whereas it can only establish traditional regulatory regimes in relation to federal legislative heads of power. ${ }^{10}$ Incentives often take the form of funds which have "strings attached" for example, in the case of certain incentive programs involving contributions" for economic development, and procurement contracts ${ }^{12}$ it is not uncommon to find stipulations that recipients establish employment equity plans, or meet environmental requirements. ${ }^{13}$ Certainly, incentives have been used in Canada to achieve policy objectives where it is difficult to imagine coercive sanctions being employed: for example, threats of fines or imprisonment to achieve research and development, to increase the birth rate, to stimulate the Canadian art and film sector, or mining exploration might raise hackles, yet each of these contexts attracts financial incentives. ${ }^{14}$ Moreover,

On the constitutional ability of the federal Parliament to create spending programs affecting provincial heads of power, see below at IV A "Incentives and the Division of Powers".

For example, pursuant to the Federal Contractors Program, it is possible for the federal government to require the implementation of employment programs for disadvantaged groups on contracting businesses and organizations which would otherwise not be subject to federal employment equity legislation. Pursuant to the Canadian Exploration Incentives Program, the federal government is encouraging exploration of, inter alia, provincial resources on provincial lands. On the division of powers question, see below at IV A "Incentives and the Division of Powers." A contribution is a conditional transfer payment that does not result in the direct acquisition of goods or services, so the money is transferred for a specific purpose, and is accounted for, or audited, pursuant to a contribution agreement: see C. 9. Treasury Board Guide on Financial Administration (Ottawa: Supply and Services) and see also House of Commons, Standing Committee on Public Accounts, House of Commons Debates No. 26-4 (15 March 1990) (per Mel Cappe, Senior Assistant Secretary, Treasury Board). Many persons confuse contributions with grants: Treasury Board makes a distinction between these two types of incentives. At the federal level, a grant is defined by Treasury Board as an unconditional transfer payment not subject to accounting or auditing, but for which eligibility and entitlement criteria are established. According to the above two sources, there need not be an agreement between government and the recipient. Finally, the words shown in the Estimates describing a grant have a legislative character while those describing contributions have only an informative character (See, eg., statement to this effect in 1989-1990 House of Commons, Estimates (Ottawa: Supply and Services, 1989) Part II at 1-4. A payment made by the government for which it will receive goods and services. Generally subject to the federal Governmem Contracts Regulations, C.R.C. 1978, c. 701.

For example, with respect to employment equity, see discussion of Federal Contractors Program, below at III "The Need for Better Legal Accountability." With respect to environmental requirements, see e.g., discussion of Pulp and Paper Modernization Program, infra note 28.

With respect to rescarch, programs include National Research Council's "Industrial Research Assistance Program," and Energy, Mines and Resources "Industrial Energy and Research and Development Program." For descriptions of these programs, see Horsley, et al., Industrial Assistance Programs in Canada 1990 - 1991 (Don Mills: CCH, 1991) paras. 80,180 and 85,110 respectively. Regarding stimulation of the birth rate, see Quebec three or more baby bonus scheme (See Quebec, Ministere de la Sante et des Services sociaux. Secretariat a la famille. Familles Quebecoises: Aide Financiere en 1990 (Quebec: Depot legal, Bibliotheque nationale de Quebec, ler trimestre 1990), and Regulation amending the Regulation respecting Family Allowances, O.C. 1816-88, 7 December 1988, pursuant to the Family Allowances Act (RSQ, c. A-17). Canada Council and Telefilm Canada provide assistance for the arts and films, pursuant to the Canada Council Act, R.S.C. 1985, c. C-2, and the Canadian Film Development Act, R.S.C. 1985, c. C-16 respectively. The most recent federal mineral exploration initiative is the Canadian Exploration Incentives Program, established pursuant to the Canadian Exploration Incentive Program Act, R.S.C. 1985 (4th Supp.), c. 27. The author is not suggesting that it would be impossible to devise a command-penalty instrument to achieve any 
just as the fingers work well in tandem with thumbs, so too it is not uncommon to find financial incentives used in conjunction with coercive instruments. For example, there are incentives to abate pollution or to hire disadvantaged groups, offered at the same time as traditional pollution control and anti-discrimination regimes are in place. ${ }^{15}$

While the thumbs of government are generally kept in check through fairly rigorous accountability mechanisms, the fingers may escape significant legal structuring. The approaches developed for circumscribing use of coercive instruments seem blunt and inadequate when directed at framing and controlling the use of financial incentives. In this sense, courts and other institutions which have developed doctrines and procedures for structuring the obvious and direct deprivations of liberty or security which lie behind use of conventional coercive instruments, are left "pushing on string"16 when faced with holding accountable the development and use of incentives. This article examines the adequacy of legal accountability mechanisms currently in place for incentives as a prelude to discussion of possible reform initiatives. The position taken here is that decision-makers must recognize incentives for what they are regulatory instruments ${ }^{17}$-and develop useful constraints on their use. It would be foolish to wait for the courts (burdened as they are by heavy armour developed to deal with coercive instruments, and capable of addressing only those aspects of accountability which fall within their jurisdictional purview) to systematically take on this responsibility.

After defining several key terms, the basic argument for the establishment and imposition of significant legal structuring of incentives is set out. Then, inadequacies with the current legal accountability framework are examined, from the formulation stage through incentive administration and enforcement. Finally, some suggestions for reform are put forward.

of these objectives. It is possible, eg., to have conditions on licences which require television stations to buy a certain percentage of programs with Canadian content. Similar techniques could be used with respect to research and development. Birth control devices could be banned in Quebec. However, in each case, it would necessitate first that a coercive regulatory regime be put into place. And it might be perceived by many as a "heavy handed" way of implementing these types of policies.

The Federal Contractors Program concerning employment equity works to achieve similar objectives to those implemented through the Canadian Human Rights Act, R.S.C. 1985, c. H-6. Incentive programs with environmental components, such as DRECT, are intended to result in reduced harm to the ecosystem, as are regulatory regimes such as the Canadian Environmental Protection Act, S.C. 1988, c. 22. DRECT (Development and Demonstration of Resource and Energy conservation Technology) is a joint Department of Environment/Energy, Mines and Resource initiative, described in Environment Canada, A Decade of Achievement: Environment and Energy Research and Development (Ottawa: Supply and Services, 1989) at 20-21.

16 The expression "pushing on string" was used by G. Ritchie to describe incentives in "Government Aid to Industry: A Public Sector Perspective" (1983) 26 Can. Pub. Admin. 36 at 37 . It is used in a different sense here.

17 That is to say, instruments used to influence or alter private sector behaviour in furtherance of an express public policy objective. 


\section{DEFINITIONS}

One of the obstacles to intelligent discussion of this topic is the tremendous potential for confusion about what is meant by several of the key terms involved. In the hopes of contributing to the development of a consistent and precise vocabulary applying to this important but understudied area of regulatory activity, various terms are defined below.

In this paper, "financial incentives" are taken to mean disbursements ${ }^{18}$ of public funds or contingent commitments to individuals and organizations, intended to encourage, support or induce certain behaviours in accordance with express public policy objectives. They take the form of grants, contributions, repayable contributions, loans, loan guarantees and insurance, subsidies, procurement contracts and tax expenditures. ${ }^{19}$ Needless to say, the ability of government to achieve desired behaviour may vary with the type of incentive in use: up-front disbursements of funds (such as with contributions and procurement contracts) may put government in a better position to dictate the terms upon which assistance is provided than contingent disbursements such as loan guarantees and insurance. In some cases, the incentive aspects of the funding come from the conditions attached to use of the monies. ${ }^{20}$ In others, the mere existence of a program providing financial assistance for a particular activity (eg. low interest loans for a nuclear power plant, or a pulp mill) may be taken as government approval of that activity, and in that sense, an incentive to encourage that type of activity has been created. ${ }^{21}$ Given the wide variety of incentive types, it will not be possible in a paper of this length to provide anything more than a cursory discussion of some of the main incentives used. ${ }^{22}$ And, needless to say, the comments made herein concerning accountability apply to differing degrees depending upon the type of incentive under consideration.

By limiting the definition of financial incentives to initiatives where public funds are either disbursed or contingently committed, a large number of regulatory programs with incentive effects which exist, but in which no money is forthcoming, ${ }^{23}$ are excluded from direct examination in this paper. Such programs might be referred to as indirect incentives. Through elimination of indirect incentives from the scope of discussion, the

18 The word "disbursement," while admittedly lacking in elegance, is used to convey the wide spectrum of ways in which public funds can be conveyed, from loans to loan guarantees, grants, contributions, allowances, deductions and so on.

For definitions of these incentives, see The Law Reform Commission of Canada, The Legal Framework for Financial Incentives as Regulatory Instruments by K. Webb (Ottawa: Law Reform Commission of Canada, 1990).

Such as with the Federal Contractors Program, where agreement to implement an employment equity plan is a condition of eligibility. Discussed in greater detail below at III, "The Need for Better Legal Accountability."

21 Other examples of this type would include the Quebec baby bonus program. and Canada Council grants or Telefilm loans for films. The existence of the Federal Environmental Assessment Review Process, and its application to federal funding projects in which there are significant environmental impacts is an indication of government recognition that funding of industrial projects can amount to incentives to engage in activities harmful to the environment: see s. 6(c) of the Environmental Assessment and Review Process Guidelines Order, SOR/84-467. 
definition of the incentive instrument becomes both more manageable and more particular. Nevertheless, it is possible that much of the approach taken here may be usefully applied to these types of indirect incentives as well..$^{24}$ Also excluded from discussion here are social assistance programs such as welfare and ad hoc industry bailout initiatives because such programs are not designed primarily to encourage behaviours in furtherance of specific public policy objectives. In effect, these programs are assistance, but they are not incentives.

The Law Reform Commission of Canada has in earlier studies defined accountability of administrative agencies as:

...[h]aving to answer for the exercise of what is essentially governmental authority to affect public and private interests. The rule of law demands that governmental authority not be exercised arbitrarily, and that agencies account, sometimes within a political framework, sometimes within a legal one, and often within both, for the decisions they make and for the policies they pursue as decision makers. ${ }^{25}$

It is readily apparent from this definition and its focus on non-arbitrary decisions made in accordance with the rule of law that the degree of accountability is dependent upon the decisions and actions of officials being confined to the express statutory limits of their authority, and to the implied limits incorporated in legal principles such as procedural fairness, natural justice, good faith and reasonableness, equality and fundamental justice. In effect, for an incentive program to be accountable there must exist authoritative, publicly accessible rules setting out how the program is to operate, and the decisions of officials must be reviewable (by courts or some other body) to ensure fairness, etc. If officials do not publish and abide by the rules of program operation, do not indicate the reasons for their decisions and do not let affected parties participate in decision-making processes, the accountability of the program can be detrimentally affected. ${ }^{26}$

Another important point to emerge from the Law Reform Commission definition is the idea that legal and political accountability overlap in significant respects. The annual reports of the Auditor General, and the work of the House of Commons Public Accounts Committee represent modest examples of political accountability in incentive operation. The information revealed by these bodies can also assist persons in their individual actions

For example, the approach to legal accountability in disbursement of incentives suggested here might or perhaps should parallel the disbursement of other government benefits, such as licences or certifications. Reform Commission of Canada, 1985) at 8-9.

26

Not discussed in this article are the legal and administrative mechanisms in place to deter Members of Parliament and the Senate, government officials, and former government officials from influencing the incentive dispensation process in a manner to their personal benefit. Under the Criminal Code, R.S.C. 1985, c. C-46, a number of offences are relevant, including s. 121 (official accepting a reward, or benefit in connection with the transaction of business of government) and $s .122$ (fraud or breach of trust by a public officer). Also relevant are provisions of the Conflict of Interest and PostEmployment Code for Public Office Holders. 
against government officials to obtain relief for alleged maladministration. ${ }^{27}$ However, at a more fundamental level, an as yet largely unrecognised problem is the ability of governments to introduce incentive programs "through the back door," by little more than votes in Appropriation Act ${ }^{28}$ which are then often elaborated upon in Treasury Board authorizations. ${ }^{29}$ An even more unobtrusive method of introducing incentive programs is through Cabinet policy directives. ${ }^{30}$ Legal accountability can be enhanced if there is insistence upon more thorough and detailed elaboration of proposed incentive programs in statutes and regulations promulgated through the normal Parliamentary legislative process (i.e., as with the introduction of conventional regulatory initiatives): where the terms of incentive programs are more fully set out in legislation and other statutory instruments, and not left to be articulated exclusively by Treasury Board (or administrators through internal circulars and other documents), the potential for arbitrary exercise of

For example, persons could learn from an Auditor General's Report or a Public Accounts Committee meeting that administrators are using unwritten eligibility criteria.

For example, the Pulp and Paper Modernization Program was established by a vote in Appropriation Act No. 5. S.C. 1973-74, c. 47. Discussed in greater detail in Law Reform Commission of Canada, Industrial Water Pollution Control and the Environmental Protection Service by K. Webb (Ottawa: Law Reform Commission of Canada, 1983) [unpublished], C. 9. The process leading to approval of programs in Appropriation Acts involves general description of the initiative in the Estimates documents, which are reviewed by appropriate Parliamentary Standing Committees, and approved by Parliament. The Estimates documents provide considerably greater detail about programs now than they did prior to the early 1980s (eg., with the addition of Part IIls), but even still they have been the subject of criticism. Thus, for example, in the Report of the Auditor General of Canada 1987 (Ottawa: Supply and Services, 1987), para 7.44. the Auditor General was critical of the descriptions of the Department of Energy, Mines and Resources programs in Part III of the Estimates (i.c., the most detailed part):

Almost without exception we found that new spending initiatives, such as those described in the previous section [e.g., FIRE] were not described consistently or adequately in Part III. Thus no basis was provided for Parliament to judge whether the initiatives would provide value for the money requested.

For a more in-depth look at this process, see D. Hartle. The Expenditure Budget Process of the Government of Camada (Toronto: Canadian Tax Foundation, 1988).

As in the case of Energy, Mines and Resource's Enerdemo program, whose terms are set out in Treasury Board authorization No. 7933 46, dated March 31, 1984.

As in the case of the Federal Contractors Program for Employment Equity, which was authorized by a Cabinet policy directive of March 8, 1985, and further elaborated upon in Treasury Board Circular 1986-44. No. 802984, dated August 25, 1986 . A separate problem is the process leading to promulgation of tax incentives, which essentially takes form with the presentation of the Budget Speech, followed by tabling and passage of tax legislation. For reasons of budget secrecy pertaining to tax measures, amendments to the Income Tax Act S.C. 1970-71-72, c. 63, normally take effect from the date that the budget speech is passed in the House of Commons, even though legislation setting out the actual changes may come months later: see, generally, E.A. Driedger, "A Comment on Budget Taxation" (1982) 30 Can. Tax J. 562 - 564. As well, tax incentives are removed from the normal budgeting process that applies to all direct outlays. The last tax expenditure account (indicating how much revenue was foregone through incentives in the tax system) was published in 1985. 
authority is reduced and the ability of all concerned to stay within the intended parameters of program operation is enhanced. ${ }^{31}$

With political accountability, Members of Parliament, and ultimately the electorate are the final arbiters of propriety (however indirect or inadequate this method of accountability might be). While mechanisms designed to ensure legal accountability should indirectly enhance the ability of MPs and the electorate to respond to problems with incentive programs, the traditional overseers of legality are, of course, the courts. As the paper discusses in more detail, judicial preoccupations with coercive regulatory initiatives and the direct potential for deprivations of rights these initiatives entail seems to have affected their ability to perceive of incentives as regulatory instruments, to take seriously the significant impact incentives can have on applicants, competitors, and the greater community, and to effectively order the administration of such instruments. It is not uncommon to see judges describe disbursements as "gratuities" or "privileges", apparently not worthy of significant legal treatment, and to characterize incentive agreements as contracts, thus potentially denying or marginalizing their public policy dimensions. The result is that affected persons have not been able to rely on the courts as the institution of final recourse in cases of maladministration to the extent that is possible with more traditional regulatory programs.

In light of these factors, it may be that non-curial bodies such as ombudsmen and tribunals or review boards are better suited to perform many accountability functions pertaining to incentive operation. In Canada at the federal level, the newly created Procurement Review Board is examining certain procurement decisions to ensure fairness and openness in the awarding process. ${ }^{32}$ It has heard and responded to numerous complaints about lack of notice, contracts being awarded to other than the lowest tender, etc. Its apparent success so far seems to demonstrate that such an entity is well suited for handling many problems with fairness and openness in commercial settings. Along the same lines, an Incentives Review Board could be established at the federal level in Canada. In England, it has been reported that a substantial portion of the ombudsperson's (there known as the Parliamentary Commissioner for Administration) energies have been successfully devoted to assisting individuals with problems receiving financial assistance. ${ }^{33} \mathrm{~A}$ Canadian federal ombudsperson with specific authority to respond to financial incentive problems could help to keep administrators accountable in their incentive decision-making.

It is fully recognized that Parliament cannot be expected to comprehensively scrutinize and approve detailed legislative provisions for every incentive program that is established, that many incentive programs are only worked out at the administrative level, and that administrators have a legitimate role to play in elaborating the terms of programs. All this having been said, however, the point remains that more detailed legislative authority for incentive programs than, for example, a vote in an Appropriation $A c t$, is both possible and desirable.

32 The Procurement Review Board is discussed in greater detail in K. Wcbb, supra note 19.

33 See discussion of this in A.W. Bradley, "Comment: Delayed Payment of a Discretionary Grant" [1989] Public Law 197 at 199. Again, the distinction between financial assistance and financial incentives is recognized, but it is submitted that use of ombudsmen in situations of alleged incentive maladministration is likely to be practicable. 
By "legal structures," it is meant the institutional and procedural framework established by law and pursuant to which incentives are introduced and delivered as well as the concepts and instruments used to describe and frame incentive arrangements. Thus, it includes constitutional aspects (i.e., the ambit of the spending power of the federal government), the law of financial management (e.g. through the Financial Administration $A c t,{ }^{34}$ Treasury Board policies, etc.), the legislative authority for and elaboration of programs, and the process leading to their introduction as well as the law pertaining to the day to day administration of incentives (e.g. the rules of procedure and eligibility for incentive applications, the form of incentive agreements, the relevance of judicial review and the doctrine of procedural faimess).

It should be emphasized that the degree of structure applicable to any particular incentive will depend upon the nature of the incentive. Factors relevant in determining the scope and content of structuring might include: the amounts of money involved, the policy context, the number of potential recipients, the number of affected parties and the degree that they are affected, and so on.

\section{THE NEED FOR BETTER LEGAL ACCOUNTABILITY}

The basic position taken here is that financial incentives should be subject to a legal structure ensuring accountability similar to that in place for traditional regulatory instruments. By this it is meant that:

(1) federal incentives with significant effects on provincial legislative heads of power should be constrained by binding federal-provincial agreements;

(2) Parliament should make a greater effort to articulate the terms of incentive programs in legislation, regulations, and other statutory instruments as they do with traditional regulatory initiatives;

(3) draft versions of incentive programs should be subject to notice and comment prior to promulgation; and

(4) the disbursement and administration of incentives should not be treated as a private commercial matter between government and recipients if there are significant public policy and private behaviour modification dimensions included in the program; rather, the program should be fully structured by public law notions of natural justice and procedural fairness.

Some might find this approach extreme and impractical and suggest that it ignores the considerable differences between traditional regulatory instruments and incentives. Undeniably, there are significant points of distinction between the two types of instruments. Most notably, there is no necessary element of compulsion associated with most financial incentives akin to the overtly coercive aspects of conventional command 
and control regulatory instruments. Put more simply, no one need accept a financial incentive and no activity is prohibited by the mere fact that an incentive has been refused to an individual. So why should incentives attract a legal structure similar to traditional regulatory instruments?

To answer this, it is necessary to adopt more of a functional as opposed to a formal perspective towards policy instruments of government. As we have seen, financial incentives, like regulatory offences and licensing regimes, are established to induce, support, encourage or discourage certain behaviours. In fact, on occasion, the two types of instruments can be used interchangeably. An example discussed by Howse, Prichard and Trebilcock in a recent issue of the University of Toronto Law Journal illustrates this point. ${ }^{35}$ Many countries including Canada have begun to deregulate their airline industry. The traditional command-penalty approach which compels airlines to fly to commercially unprofitable destinations as a condition of their licences may give way to an incentive scheme in which subsidies are offered to induce airlines to service outlying communities.

What does it matter which approach is taken? Decisions made with respect to airline routes under the former regulatory system were part of a publicly disseminated and discussed air transport policy, carried out by a visible, centralized public agency dedicated to the task of regulating the airlines, accessible by the affected parties and the public and subject to procedures tending to ensure accountability of the decision-makers. In contrast, airline subsidies may be doled out pursuant to a low profile departmental program so that administrators may be able to avoid providing notice to the public, hearing opinions of those affected prior to making decisions and supplying reasons for their actions. ${ }^{36}$

Of course, a primary objective of deregulation is that it reduce the "red tape" (and hence the cost) associated with traditional regulatory approaches. But, as this example illustrates, a lot more than just "red tape" may be lost by switching to use of the subsidy technique, and arguably these additional losses of accountability and fairness are significant. Thus, it is submitted that the critical question is, "Why shouldn't all instruments of government designed to alter, encourage or discourage behaviour be the subject of legal constraints to ensure that they operate in a fully accountable manner?" Surely less direct techniques intended to affect private sector behaviour should not escape critical legal attention simply because they do not resemble the conventional coercive model. This does not necessarily mean that, for example, a full fledged "Airline Subsidies Tribunal" be created. But certain minimal legal structures are desirable, in an effort to ensure, for example, that affected persons:

- are aware of the existence of the program in draft and final form through official channels (eg., announcement in the Canada Gazette, and Regulatory Plan);

$35 \quad$ "Smaller or Smarter Govemment?" (1990) 40 U.T.L.J. 498 at 534.

36 From an economic standpoint, another key point of distinction is that the command and control approach in effect makes other travellers subsidize the airline to fly to those unprofitable destinations, whereas the subsidy technique makes the entire taxpaying public chip in for the objective of getting air service to outlying regions. 
- have notice of pending decisions affecting them through official channels;

- are notified of the existence of a binding, officially sanctioned complaints procedure, which is published in an official document (preferably a statute or regulation), available to all persons, and is applied consistently to all;

- can make representations concerning these decisions through regularized channels;

- $\quad$ can determine the procedures pursuant to which subsidies are disbursed; and generally

- can meaningfully participate in the process.

In many respects, these types of concerns are reflected in the federal government's Citizen's Code of Regulatory Fairness. ${ }^{37}$ Thus, for example, the Code provides that government should encourage full consultation and participation in the federal regulatory process, ${ }^{38}$ that early notice of initiatives be given, ${ }^{39}$ communication in clear language of regulatory requirements be provided, ${ }^{40}$ and that discretionary powers be exercised in a predictable manner. ${ }^{+1}$ Unfortunately, however, the Code is apparently intended to apply only to "regulatory initiatives" where there is a threat of a sanction. ${ }^{42}$ Given the undeniable and intended impact of financial incentives on individuals as a means of achieving public policy objectives, it is suggested here that there is no defensible reason why the general approach and principles set out in the Code should not apply with equal force to incentives as it does to conventional regulatory instruments.

It should be emphasized that not all incentives lack an adequate legal structure. Some, such as the Canadian Exploration Incentives Program, are established pursuant to a specialized statute. The regulations set out the detailed operation of the program. ${ }^{43}$ Moreover, draft regulations for this initiative were subject to extensive notice and comment before promulgation. ${ }^{4}$ Furthermore, a complaint/review process has been established by CEIP administrators and made known to CEIP applicants; in addition,

See Office of Privatization and Regulatory Affairs, Federal Regulatory Plan 1990 (Ottawa: Supply and Services, 1989) at xi.

lbid. s. 2.

Ibid. s. 3.

Ibid. s. 5.

lbid. s. 14.

Below at IV C. "Notice and Comment." It will be demonstrated that there is a "threat of sanction" with some incentive programs. Incentive Program Regulations, SOR/89-123. Other examples of incentives subject to thorough structuring are Canada Council grants, and tax incentives. 
advance rulings are provided and interpretation bulletins concerning CEIP operation are made available. ${ }^{45}$

The fact that this comprehensive legal structure has been established for CEIP is ample evidence that accountability for financial incentives is not only feasible, it is even practised in some cases. But unfortunately, CEIP is the exception and not the rule. ${ }^{46} \mathrm{Far}$ more incentive programs have slender legislative foundations while the bulk of the terms of the initiative are left to be elaborated informally by administrators. The result is that such programs have not been scrutinized in draft form as have traditional regulatory instruments, nor are the terms of the program binding and publicly disseminated as would be regulations. The potential for "unwritten criteria" to be developed and applied by administrators is greatly increased in such circumstances. Where such unwritten rules exist, the likelihood for allegations of arbitrariness is greatly increased. This very circumstance has occurred and is documented with respect to a program known as Enerdemo. ${ }^{47}$ Because there is usually no appeal structure put in place, applicants are left at the mercy of the courts to sort through the informal bureaucracy and find some type of a binding obligation on administrators. Suffice it to say that at the present time judges have been slow to attach significant procedural obligations in such situations. Unsatisfied applicants may be reluctant to resort to the courts for other reasons as well: "rocking the boat" about a current application may mean informal reprisals when future programs are introduced. ${ }^{48}$

Perhaps the best example of the anomalous and less rigorous legal treatment afforded incentives when compared with conventional regulatory instruments is with respect to the federal government's "Employment Equity" initiatives. The aim of the initiatives is to achieve equal access to employment opportunities for all Canadians by directly involving and assisting employers in the implementation of employment equity. ${ }^{49}$ Two different programs have been put in place. On the one hand, all those persons who employ more than one hundred employees on or in connection with a federal work, undertaking or

45 E.g., see Energy, Mines and Resources, Canada, "Canadian Exploration Incentive Program (CEIP): A Departmental Perspective," in S. Cook et al., eds., Mineral Resource Exploration and Development (Vancouver: Continuing Legal Education Society of British Columbia, 1989) C. 1.2.

As a general rule, it would appear that those incentives which are available as of entitlement (eg., upon meeting certain conditions, funds are provided), such as CEIP and tax expenditures, attract considerably more thorough legal structuring than discretionary incentives. While it is obvious why entitlement incentives should be thoroughly structured, it is equally self-evident that discretionary incentives need significant structuring to ensure that administrators only disburse incentives:

(1) as per Parliament's intent when it approved the program; and

(2) in a fair, open and accountable manner.

47 See Energy, Mines and Resources, Canada, Phase I Evaluation of The Enerdemo Program Final Report, PE 129A/1988, July 1988, at 15 and 28.

48 C. A. Reich, in "The New Property" [1964] 73 Yale L.J. 733 at 751, said as follows:

Seeking to stay on the safe side of an uncertain, often unknowable line, people dependent on largess [sic] are likely to eschew any activities that might incur official displeasurc. Beneficiaries of government bounty fear to offend, lest ways and means be found, in the obscure corners of discretion, to deny these favours in the future.

s9 Per Employment and Immigration, Canada, Employment Equity: A Guide for Employers (Ottawa: Queen's Printer, undated) at 1. 
business as defined in the Canada Labour Code ${ }^{50}$ are required to establish employment equity work plans, and to submit them to government for approval and monitoring pursuant to a separate statute and regulations. ${ }^{51}$ On the other, a "Federal Contractors Program" has been established by the considerably less public and formal method of a Cabinet policy directive to achieve essentially the same thing. ${ }^{52}$ Rules for contractors are developed in an ad hoc way which gives administrators "the luxury of flexibility," ${ }^{33}$ but potentially detracts from faimess and accountability in program operation. With a few exceptions, all federal procurement contractors employing more than 100 persons who have government contracts of more than $\$ 200,000$, must comply with this program. ${ }^{54}$ If they do not, the ultimate sanction is debarment (i.e., the loss of the opportunity of doing further business with the government). ${ }^{5.5}$

R.S.C. 1985, c. L-2. By s. 2 of the Code, a "federal work, undertaking or business" is one which is within the federal legislative authority, including one in connection with navigation and shipping, inter-provincial transportation, radio broadcasting and banking. The Employment Equity Act, R.S.C. 1985 (2nd Supp.) c. 23, and Regulations, SOR/86-847. Supra note 49 at 1 . See also N. Cullen (then Director of the Federal Contractors Program), "Federal Contractors Program" (Employment Equity Seminar, Queen's University, 8 June 1990) [unpublished] at 4. Compare with s. 23 of the Canadian Human Rights Act, R.S.C. 1985, c. H-6, which authorizes the Governor in Council to make regulations respecting terms and conditions to be included in or applicable to any contract, licence or grant made or granted by Her Majesty in right of Canada providing for

(a) the prohibition of discriminatory practices; and

(b) the resolution of complaints of discriminatory practices contrary to such terms and conditions.

See also s. 17 of the Department of Supply and Services Act, R.S.C. 1985, c. S-25, which authorizes the Minister of Supply and Services to "by order, prescribe general terms and conditions for contracts that he may enter into under this Act...." Pursuant to s. 7 of the same Act, the Minister may delegate any of his powers, duties or functions to another Minister. Per Cullen, ibid.

st The program applies to all contracts for goods and services, but not to the purchase or lease of real property, construction contracts, or to the performance of legal services entered into under the authority of the Minister of Justice: per Treasury Board Circular No. 1986-44, TB No. 802984, dated 25 August 1986, point 5, and Employment and Immigration. Canada, Employment Equity: Federal Contractors Program Questions and Answers (Ottawa: Supply and Services, 1987) at 1. To qualify for a federal contract, aspiring suppliers must sign a "certificate of commitment" certifying that they will implement an employment equity program in keeping with a pre-determined set of criteria. For discussion of this, see $\mathrm{N}$. Cullen, supra note 52 at 4-5. Implementing an employment equity program entails the identification and removal of artificial barriers to the selection, hiring, promotion and training of women, aboriginal peoples, persons with disabilities, and visible minorities. Moreover, contractors must take steps to improve the employment situation of these designated groups by increasing their participation at all levels and in all areas of the work force: per Treasury Board Circular No. 1986-44, supra point 3. Another essential component to the implementation process is the introduction of special measures and the establishment of internal goals and timetables towards the achievement of employment equity by increasing the recruitment, hiring, training and promotion of designated group members and by making reasonable accommodations to enable members of such groups to compete with others on an equal basis: per CEIC Circular WH-3-590, Employment Equity, "Information for Suppliers," Implementation 2(c). Contractors must also retain records regarding the employment equity implementation process for assessment by officials from the CEIC during on-site compliance reviews. [lbid. at sub dl. For more complete description of the program see K. Webb, supra note 19. 
The regulatory effect of both programs cannot be denied. They both address the same perceived mischief and impose obligations and costs on private sector actors. Yet the legal structure (and thus the accountability) of one regime (i.e., the Contractors Program) lacks any meaningful statutory basis. ${ }^{56}$ This is not to deny that there are important differences between the two programs. It is true, for example, that the Employment Equity Act regime compels compliance on pain of penalty, whereas the Contractors Program only requires commitments from those contractors who have "voluntarily assumed" a procurement relationship with the federal government. But this distinction surely does not warrant such starkly contrasting legal structures. In one case, compliance is "coerced", in the other, it is "bought." ${ }^{.57}$ In effect, in both cases, administrators are wielding considerable power to achieve public policy. Their object is to induce certain behaviours. Accomplishment of that object is by financial pressure and will affect not only the regulated individuals, but also a greater community of beneficiaries. Taking a functional rather than a formal approach to the initiatives, it is suggested that the legal framework for establishment and delivery of incentive programs should be similar to that existing for traditional regulatory programs. Interestingly enough, in 1986, a coalition of disadvantaged groups specifically called for legislation to cover federal contractors. ${ }^{58}$

Legally trained persons must be careful not to impose their values on the world. It is no doubt true, for example, that rule-bound, formalistic approaches to regulatory initiatives are not appropriate in all situations. Administrators need a modicum of flexibility in order to address widely diversified situations. Moreover, determining the right degree of accountability for a particular financial incentive program is complicated by the fact that incentives straddle the elusive border between public and private law. ${ }^{59}$ Public law fixations with fairness and accountability must be weighed against more ubiquitous concerns with efficiency and predictability. ${ }^{60}$ Nevertheless, the position taken here is that a minimum amount of legal framework beyond a simple statutory authorization is necessary for the proper establishment and operation of many incentive programs.

While it may be felt that many officials would be against development of legal regimes having the effect of structuring and confining their acts and decisions, in fact this is not always the case. In the course of the author's research several administrators came forward on their own initiative seeking assistance in developing greater legal structure for their incentive programs. Their reasons for doing so were varied: in some cases, to

s6

I.e., the Federal Contractors Program was not tabled in the House of Commons, the terms of the program are not set out in a publicly accessible, statutory instrument, and there was not any Gazetting of the detailed provisions of the program, comparable to that of a conventional regulatory instrument. In fact, in most regulatory offence regimes, the direct threat in the overwhelming number of cases is not a loss of liberty (eg, imprisonment), but instead a monetary loss. Looked at this way, an offence regime can be described as a negative financial incentive (i.e., a disincentive). "Mandatory or voluntary affirmative action?" (1986) 2:2 Can. H.R. Advoc. 14.

This is perhaps no more clearly illustrated than by the use of "contracts" (a private law instrument) to implement public policy objectives.

Public administration is of course keenly concerned with efficiency and predictability, and private law relations are governed by notions of fairness, but, for obvious reasons, it would appear that a considerably higher priority is given to the values of openness, accountability and fairness in public policy contexts. 
increase the legitimacy of their actions in the eyes of their applicants and in others, to achieve greater certainty that their regimes did not offend legal principles such as procedural fairness. It is suggested that the legal structure associated with incentives should be modelled after traditional regulatory command and control regimes. The exact content of the legal structure will vary with each incentive under consideration. Nor should it be maintained that legal accountability is necessarily a hopelessly expensive proposition; in the long run, this type of accountability should lead to more informed choices about programs and delivery which will hopefully result in better thought out and less expensive initiatives.

\section{ACCOUNTABILITY IN INCENTIVE FORMULATION}

\section{A. INCENTIVES AND THE DIVISION OF POWERS}

From a constitutional standpoint, courts have for the most part refused to attach any real limits on the federal "spending power," so that programs may be established which directly affect provincial heads of legislative power. ${ }^{61}$ One Canadian commentator has stated that the federal government in using its financial powers is bestowing "gifts", and is free to provide gifts to whomever it chooses. ${ }^{62}$ The difference between a friendly uncle providing a tricycle to a relative on condition that he be a "good boy" on the one hand, and the federal government giving a contract or grant or loan guarantee to a company if they meet certain environmental or employment standards on the other, are hopefully selfevident. While the one court decision which explores the issue in some depth ${ }^{63}$ contains language which seems to indicate full recognition of the federal spending power's encroaching potential ${ }^{\text {si }}$ the generally accepted interpretation put on this case is that only compulsory regulation can invade provincial legislative heads of power, whereas federal spending or lending or contracting can be to any government or individual on whatever terms it chooses, since the program is not imposed on anyone. ${ }^{65}$

Although for at least the past 30 years there has been an active dissenting position which holds that federal spending should be limited to federal legislative heads, ${ }^{66}$ this view has not taken hold at the judicial level. Andrew Petter, the most recent proponent

E.g., see comment to this effect by P. Hogg, Constitutional Law of Canada, $2 \mathrm{~d}$ ed. (Toronto: Carswell, 1985) at 126.

F.R. Scott, "The Constitutional Background of Taxation Agreements" [1955] McGill L.J. 1 at 6. Attorney-General for Canada v. Antorney-General for Ontario et al., [1937] A.C. 355 (the Unemployment Insurance case).

E.g. " "Legislation which disposes of funds collected by taxation] may still be legislation affecting the classes of subjects enumerated in s. 92, and, if so, would be ultra vires." "If...in pith and substance the legislation invades civil rights... or ...otherwise encroaches upon the provincial field, the legislation will be invalid. To hold otherwise would afford the Dominion an easy passage into the Provincial domain," per Atkin J. in the Unemployment Insurance case, ibid. at 366-367. E.g., see P. Hogg, supra note 63. For the most recent indication of judicial support for this position, see Brown et al. v. YMHA Jewish Community Centre of Winnipeg Inc. et al., [1989] 4 W.W.R. 673 (SCC).

6. E.g., see "Federal Grants to Universities" in P.E. Trudeau, Federalism and the French Canadians (Toronto: Macmillan, 1968). More recently, see A. Petter, "Federalism and the Myth of the Federal Spending Power" [1989] 68 Can Bar Rev. 448. 
of this approach, has argued convincingly that shared-cost programs ${ }^{67}$ detrimentally affect the principles of federalism, responsible government and accountability. He points out that federalism, with its characteristic division of powers between two levels of government, is a democratizing force because it provides citizens greater influence over policies that have been assigned to regional governments than they would have over those assigned to a central government. ${ }^{68}$ Federal influence over provincial policies through the spending power is seen by Petter to compromise political accountability and thereby weaken the ability of electors to exercise democratic control over government by blurring the delineation of responsibilities.$^{69}$ Interestingly, similar arguments have been made (to no avail) in the United States. ${ }^{70}$ One American commentator suggests that "[t]wo hundred years of Congress tempting states with money and land grants have, indeed, reduced state governments to mere field offices of the vast federal bureaucracy. ${ }^{171}$

Thus, analysis suggests that in spite of the problems that may arise from indiscriminate use of federal incentive programs, the impetus for reform is not likely to come from the courts: it is generally accepted that the federal government has the constitutional authority to create incentive programs affecting provincial heads of power and the only direct constraints at this point are political, not legal. If constitutional constraints are to be put in place concerning use of the spending power, it is Parliament and the provincial legislatures which must take the initiative. In this regard, the ill-fated Meech Lake Accord did contain some provisions which attempted to address aspects of this issue. ${ }^{72}$ Notwithstanding its weaknesses, the Meech Lake Accord can be taken as political recognition that the current unrestrained use of the federal spending power is no longer considered tenable.

\section{B. LEGISLATIVE ELABORATION OF INCENTIVE PROGRAMS}

As was mentioned earlier, in contrast to most traditional regulatory initiatives, incentive programs may be established pursuant to little more than a one sentence authorization in a vote to an Appropriation Act, building on a general power to "establish programs" contained in legislation. ${ }^{73}$ Incentive programs have also been created by Cabinet policy directive. ${ }^{74}$ The practice of using Appropriation Acts as authorities for programs has been

Many federal incentive programs are of the "shared-cost" variety, eg., the Pulp and Paper Modernization Program, and certain components of Enerdemo. With such programs, both federal and provincial governments contribute funds which finance the program.

A. Petter, supra note 66 at 464.

Ibid. at 467. Note that the focus of Petter's work is on federal-provincial shared cost programs.

R.B. Capalli, "Restoring Federalism Values in the Federal Grant System" (1987) 19 Urban Lawyer 493.

Ibid. at 501 .

See, in particular, Clause 7 of the Accord. Note, however, that the Accord focused on "shared-cost" programs.

For an example of an incentive program established by a general statutory authorization power, see, e.g., the federal Acid Rain Abatement Incentive Initiative, established by the Department of Regional Industrial Expansion Act, R.S.C. 1985, c. R-5, repealed 1990, c. 1 s. 23, s. 5.1, and s. 6(3) of the Department of the Environment Act R.S.C. 1985 c. E-10 repealed R.S.C. c. 16 (4th supp.) s. 146. E.g., the Federal Contractors Program, discussed infra at III. 
approved by the courts ${ }^{75}$ but frowned upon by the Speaker of the House. ${ }^{76}$ Attaching public policy objectives such as requirements that recipients use Canadian products or services, establish employment equity programs or meet environmental protection standards in otherwise unrelated initiatives, ${ }^{77}$ in the absence of a specific authority to do so, is at best a dubious practice. ${ }^{78}$ If authorization for such programs, and/or elaboration of their terms is not contained in legislation, Parliament is not provided the opportunity to consider the implications of such programs. Moreover, the authoritative guidance provided to administrators responsible for disbursing funds (not to mention to potential recipients, affected communities, etc.) will be minimal. The potential for administrators acting in a manner outside of program terms is increased when there is no binding articulation of program terms set out in legislation. ${ }^{79}$ Again, it would appear self-evident that the impetus for reform must come from Parliament, not the courts.

\section{NOTICE AND COMMENT}

There has developed at the federal level in Canada a process whereby "regulatory initiatives," before promulgation, are first to be "previewed" through the Regulatory Plan and Canada Gazette Part I notice and comment provisions. ${ }^{80}$ This process provides individuals with an opportunity to become aware of upcoming initiatives and to influence the shape of them (perhaps even pre-empt them) before they come into effect. This type of process can lead to cost efficiencies for government in the sense that poorly thought

In Carota v. Jamieson. Lessard and Altorney-General of Canada, [1979] I F.C. 735 at 743, Marceau J., speaking for the Federal Court Trial Division commented that...

[t] he power given by an Appropriation Act [to create a shared cost program] is, of course, as valid and adequate as that conferred by any specific Act...and such power embodied in the wording of a vote does not lapse at the end of the contemplated fiscal year.

The Federal Court of Appeal essentially agreed with the Trial Division on this point: [1980] 1 F.C. 790 at 799.

See House of Commons Debates ( 12 June 1981) at 10546, on a point of order brought by Mr. Andre. Madam Speaker summarized earlier rulings from the Chair to the effect that "...the Appropriation Act is not the place to seek authority to do something such as to establish a program. Rather, the Appropriation Act should only seek authority to spend the money for a program that has been previously authorized by a statute." The difficulty would appear to be in the determination of when a program "has been previously authorized by a statute." Does a general power in a statute to "develop and implement programs..." suffice? See, for example, s. 9 of the Department of Industry. Science and Technology Act. S.C. 1990, c. 1 which states as follows:

Where the Governor in Council is of the opinion that it is in the national interest to do so, the Minister may develop and implement programs and projects of special assistance to industries....

E.g., in a procurement contract for goods and services, or in a regional development loan, contribution, grant, etc.

Quaere, if an affirmative action program attached to a regulatory approval for an energy development project is considered ultra vires the jurisdiction of the approving agency in the absence of express language providing such authority (Re Athabasca Tribal Council and Amoco Canada Petroleum Co. Ldd. et al (1981), 124 D.L.R. (3d) I (SCC)), would not similar conditions attached to unrelated funding programs be equally suspect? If not, is this not another example of governments being able to regulate indirectly what they cannot regulate directly? See, for example, discussion of administrators creating unstated eligibility criteria for the Enerdemo program, supra note 47 and accompanying text. 
out or designed programs can be halted, reassessed and/or altered before any serious problems have developed; moreover, the process can in the long run, improve the likelihood of compliance with program objectives since affected persons have early notice of upcoming programs and can begin to plan accordingly (hopefully in a positive sense).

The Regulatory Plans require the federal government and departments to submit information in the fall of each year outlining proposed "regulatory initiatives" for the upcoming year. These are compiled and published, along with a brief description of the initiative, estimate of anticipated impact (cost), statutory authority, and contact person within the initiating agency. In the abstract, the term "regulatory initiative" is broad enough to include all types of financial incentives. The issue of the Regulatory Plan which came closest to defining "regulatory initiatives" ${ }^{11}$ included a statement that "[r]egulation...happens when a government uses law to control or prevent certain types of human behaviour and backs it up with the threat of a sanction. ${ }^{182}$

On its face, this definition would appear to exclude incentives from its scope, because while incentives may have the effect of discouraging certain conduct (eg., it could be said that affirmative action programs dissuade employers from engaging in discriminatory activities by promoting the hiring of disadvantaged groups), they only indirectly prevent or control it, and the most effective sanction is often foreclosure from being eligible to receive future benefits. ${ }^{83}$ In fact, it would appear that the term "regulatory initiative" as used in the Regulatory Plan is synonymous with Governor in Council approved "regulations", "orders in councils", and amendments to same (i.e., statutory instruments). Thus, for example, pending draft amendments to the regulations for the Canadian Exploration Incentive Program (CEIP) were announced in the Regulatory Plan. ${ }^{84}$

The author could find no announcements in the Plan of draft rules regarding incentive programs which would not take the form of regulations or orders in council. ${ }^{85}$ This is hardly surprising. Many of these programs have slim legislative foundations while the operational aspects are left to be worked out in piecemeal fashion in brochures, directives, guidelines etc. by administrators not pursuant to any formal, Cabinet approved instrument.

Office of Privatization and Regulatory Affairs, Federal Regulatory Plan 1987 (Ottawa: Supply and Services, 1986).

Ibid. at xiii (emphasis added).

From a definitional standpoint, sanctions can be both penalties for disobedience or rewards for obedience (Concise Oxford, 7th ed., U.S.A.: 1983, at 926), but a "threat" of a sanction indicates that the authors of the Regulatory Plan had a negative sanction in mind. In the case of the Employment Equity Federal Contractors Program, the eventual sanction is removal from the federal government's list of potential contractors. There is no doubt that this could be perceived as a negative sanction. With other incentive programs, not part of an ongoing government activity such as procurement, the "threat" that an applicant will not be considered for future programs (while very real) does not lead to an institutionalized "debarment procedure" as with procurement contractors, and so may be less effective.

Supra note 37 at 71 . The CEIP initiative is a somewhat anomalous case amongst current federal financial incentives, noteworthy for the fact that it was promulgated pursuant to its own statute and involves expenditures of over $\$ 200$ million.

Other examples of draft incentive orders/regulations announced in the Regulatory Plan include the Indian Economic Development Direct Loans, and Loan Guarantees, ibid. at 154. 
Although many of these programs might not involve enormous expenditures, this by itself is no reason to disqualify them from inclusion in the Regulatory Plan: many of the initiatives announced in the Plan are inconsequential (e.g., minor technical changes to regulations), yet they are included just the same. In light of the fact that in practice the Regulatory Plan excludes "regulatory initiatives" such as incentive programs articulated in a form other than regulations or orders in council, several reform options are open: incentive programs could be established in the same manner as the CEIP initiative (i.e., by ordinary legislation, with the detailed terms to be articulated in regulations), or the definition of "regulatory initiatives" in the Plan be broadened to include administrative elaborations (which lack formal executive approval) of program terms. Alternatively, a new advanced notice and comment process and registry could be established for initiatives which do not take the form of statutory instruments.

A second opportunity for public comment comes when "the detailed test and the impact analysis for significant regulations are "prepublished" in Part I of the Canada Gazette. ${ }^{\text {"86 }}$ As to whether or not incentive programs qualify as "significant regulations", this would seem to depend on how the term is defined. If the traditional notion of regulation as "use of law to control behaviour backed by sanction" (supra) is adopted, and if Cabinet approval is a prerequisite, then clearly many incentives could escape publication in the Gazette. However, it appears a somewhat less traditional definition is being used (at least recently): copies of draft guidelines for an indirect incentive program (promulgated by order in council and authorized by statute) have been published in the Gazette Part $1 .{ }^{87}$ This suggests a slightly more broad definition of "significant regulations" has been adopted by Gazette Part I officials than by those persons responsible for compiling the Regulatory Plan.

\section{ADMINISTRATIVE ELABORATION OF INCENTIVE PROGRAMS}

Once a program has been put into place, it is common that the responsible department or agency will devise policies or guidelines which interpret and "flesh out" the basic statutory rules of operation of a program. This is true both for traditional regulatory initiatives and incentive programs but it is particularly important with respect to incentives because the statutory terms are, as we have seen, more likely to be lacking in any meaningful detail. The opportunity for administrators to develop unwritten or at least unpublicized rules or criteria is increased where the legislative foundation is minimal. In turn, the likelihood of effective accountability is reduced. There are recorded incidents of this type of problem arising with respect to incentive programs: participants in one incentive program with a slender legislative basis are reported to have found the disbursement process to be "arbitrary" ${ }^{88}$ Courts have upheld the ability of administrators

From Federal Regulatory Plan 1990, ibid. at vii.

E.g., see Department of Environment, Canada, National Guidelines for Batteries: Zinc Air, C. Gaz. 1990.I.703. These guidelines pertain to the Environmental Choice Program. It would appear likely that the characteristic of the guidelines which triggered publication in the Gazette was the fact that they were published by order in council.

88 E.g., Energy, Mines and Resources, Phase I Evaluation of the Enerdemo Program Final Report, PE 129A/1988, July 1988, at 15 and 28. 
to formulate policy guidelines for the exercise of discretionary authority vested in them. ${ }^{89}$ However, judges have noted the necessity of affected parties being made aware of the rules which apply to them. ${ }^{90}$ Moreover, it has been held that affected persons should have the right to comment on rules which apply to their situation. ${ }^{91}$

While administrators may have the authority to articulate rules for programs, they might choose not to do so. At the substantive level, this means that discretionary decisionmaking can lack any useful structuring. ${ }^{92}$ At the level of procedure, officials may fail to establish a complaints process. ${ }^{93}$ Short of an explicit statutory duty to elaborate rules, there would appear to be no legal method of compelling administrators to create them. The effect can be to leave unsatisfied applicants and recipients "in the dark," not knowing what rules might be applied, or how.

In summary, the practice of administrators articulating rules which provide the detail concerning program operation has been approved by the courts, but judges have stipulated that affected parties are to be notified of the existence of such rules and be given the opportunity to explain how they do or do not apply to their situation. On the other hand, courts seem to be wary of administrators improperly fettering their discretion through such

E.g., Griffin et al. v. Canada (1989), 26 F.T.R. 185 (regarding certification of potato crops) [hereinafter Griffin]. See also British Oxygen Co. v. Minister of Technology, [1971] A.C. 610 [hereinafter British Oxygen].

E.g., Chinook Aggregates Lid. v. Abbotsford (Mun. Dist.), [1990] I W.W.R. 624 (B.C.C.A.); Thomas

C. Assaly Corporation Lid. v. R. et al., [1990] 44 Admin. L.R. 89 (Fed. T.D.); British Oxygen, ibid.

E.g., British Oxygen, supra note 89 . The same position has been stated even more emphatically in relation to certification/licensing application processes: see, Griffin, supra note 89, and Burlock v. Dispensing Opticians of N.S., [1989] 36 Admin. L.R. 59 (N.S.S.C.). As to the ability of courts to review such administrative rules under the Charter, see K. Swinton, "Application of the Canadian Charter of Rights and Freedoms" in W.S. Tarnopolsky \& G.A. Beaudoin, eds, The Canadian Charter of Rights and Freedoms (Toronto: Carswell, 1982) 41 at 49-53.

E.g., pursuant to the Industrial and Regional Development Program (established by the Industrial and Regional Development Act, R.S.C. 1985, c. I-8 and further elaborated upon in regulations (e.g., SOR/83-599, as amended)), the federal Department of Regional Industrial Expansion (as it then was) could provide direct assistance to certain industries in all parts of Canada, in the form of grants, contributions, repayable contributions, loans and loan guarantees. The Act contains general criteria relating to project eligibility and the need for DRIE assistance: a project must make a "significant contribution" to the "social or economic benefit of Canada," and the project must be commercially viable (s. 8). Auditor General findings in 1985 indicated that the "commercial viability" requirement was interpreted differently in different regions. Guidelines elaborating on these criteria were not developed. It is immediately evident that in an environment such as this, administrators are capable of disbursing incentives almost as they see fit. Indeed, the Auditor General noted that the "IRDP was seen as the Departments' main assistance tool regardless of how well the project fit the legislation, regulations or directives." Report of the Auditor General 1985, supra note 28 at para. 12.40 (emphasis added).

9. Complaints procedures have been created for the Canadian Exploration Incentives Program (see e.g., Energy, Mines and Resources Canada, "The Canadian Exploration Incentive Program (CEIP)" supra note 43 and the Federal Contractors Program (see, e.g., Treasury Board Circular 1986-44, supra note 43 and accompanying text at points $10-15$, and Employment and Immigration Canada, Employment Equity: Federal Contractors Program Questions and Answers, supra note 54 at 8-9), but there was no established complaints/review procedure for the Pulp and Paper Modernization Program nor Enerdemo. 
rules. The point of distinction between administrative rule-making in traditional regulatory settings and rule-making by administrators regarding incentive programs, is that with incentive programs, the administrative rules often times represent the only public articulation of meaningful program terms. Thus, with incentive programs, administrative rule-making is pivotal to program operation, and in need of significant safeguards to ensure that affected parties are notified of draft rules and actual rules in place, and are provided the opportunity to comment on them.

\section{ACCOUNTABILITY IN INCENTIVE ADMINISTRATION AND ENFORCEMENT}

Holding officials legally accountable for their decisions and actions in the administration of financial incentives may appear at first glance to be a straightforward matter: common law doctrines such as natural justice, procedural fairness and reasonableness, and Charter concerns with equality and fundamental justice all appear to be applicable. While it is undoubtedly true that all of these principles do apply to a certain extent, in practice effective legal accountability has been limited by a number of factors. The major principles at play and impediments to their meaningful application are discussed below.

\section{A. REASONABLENESS IN INCENTIVE ADMINISTRATION}

The ability of persons to challenge government decisions and actions as unreasonable or in bad faith is an important technique for ensuring administrative accountability in our legal system. Where programs lack detailed legislative or regulatory foundation, administrators are put in the position of having to "flesh out" program terms, and the opportunities for disputes to arise as to the reasonableness of their decisions and actions increase. This is more of a problem for discretionary incentive programs than those in the nature of entitlements ${ }^{94}$ since typically the latter are fairly extensively structured in legislation and other statutory instruments. ${ }^{95}$

A point of departure for understanding court treatment of allegations of unreasonableness in discretionary incentive settings is the House of Lords decision of

Tax incentives plus a small number of grant programs create what amounts to entitlements for applicants to receive incentives upon their meeting certain conditions of eligibility. For discussion of the entitlement nature of tax incentives see, e.g., W.A. Sheaffer Pen Co. Lid. v. M.N.R., |1953| Ex. C.R. 251 at 255, Thorson J., and Stubart Investments Lid. v. R., [1984] 10 D.L.R. 1 at 31-32, Estey J. For an example of an entitlement grant program, see, e.g., the Canadian Exploration Incentive Program, supra note 43 and accompanying text.

E.g., the tax regime is exhaustively set out in legislation, regulations, interpretation bulletins, information circulars, and so on. The Canadian Exploration Incentive Program operates in a similar manner. See, e.g., Energy, Mines and Resources Canada, "The Canadian Exploration Incentive Program (CEIP)" supra note 43 and accompanying text. Thus, with such regimes there is a greater likelihood that disputes will centre around interpretations of specific provisions, and not be framed in terms of unreasonableness. E.g., see Mobil Oil Canada Lid. v. Petroleum Incentives Administration on behalf of the Ministry of Energy Mines and Resources (12 September 1984), No. A-1150-83 (Fed. C.A.). 
British Oxygen Co. v. Minister of Technology. ${ }^{96}$ In that case, the court was considering an incentive scheme similar in some respects to Canadian discretionary modernization programs. The court characterized the discretion to grant incentives as being "unqualified" that no person had a right to receive public funds. Lord Reid, with whom the majority of the court agreed, stated as follows:

If the Minister who now administers the act, acting on behalf of the Government, should decide not to give grants in respect of certain kinds of expenditure, I can find nothing to prevent him. There are two general grounds on which the exercise of an unqualified discretion can be attacked. It must not be exercised in bad faith, and it must not be so unreasonably exercised as to show that there cannot have been any real or genuine exercise of discretion. ${ }^{97}$

Short of egregious examples of bad faith, the challenge becomes determining what constitutes a discretionary act or decision so unreasonable as to amount to a lack of any real exercise of discretion.

The author has not located any Canadian cases concerning incentives where allegations of bad faith or unreasonableness have been made; however, a similar challenge to another benefit dispensing activity ${ }^{98}$ - the granting of an import permit - has been the subject of a Supreme Court of Canada decision. In Re Maple Lodge Farms Ltd. and Government of Canada et al. ${ }^{99}$ the court considered whether the federal Minister had any discretion at all to refuse applications for chicken import permits, and if he did, whether he refused to issue the permits for irrelevant reasons. The Court held that the Minister had discretion and was entitled to promulgate and refer to guidelines as a general rule in the exercise of his discretion, provided he not fetter his discretion by treating the guidelines as binding upon him. ${ }^{100}$ The Court went on to note as follows:

Where the statutory discretion has been exercised in good faith and, where required, in accordance with the principles of natural justice, and where reliance has not been placed upon considerations irrelevant or extraneous to the statutory purpose, the courts should not interfere. ${ }^{101}$

Courts have held that where a Minister's decision would frustrate the policy of the act, they are entitled to interfere. ${ }^{102}$ The Supreme Court of Canada has also recently stated that "...the failure of an administrative decision-maker to take into account a highly relevant consideration is just as erroneous as the improper importation of an extraneous consideration...." 103

\section{\% Supra note 89.}

$97 \quad$ lbid. at 624.

98 As regards the significance of the distinction between incentives and other types of benefit dispensations, see discussion above at II "Definitions." [1982] 137 D.L.R. (3d) 558.

lbid. at 561 .

lbid. at 562.

102 Padfield v. Minister of Agriculture, Fisheries and Food, [1968] A.C. 997 (H.L.) The policy and objects of the Act were determined from a reading of provisions from the statute. 
The difficulty with these decisions, as applied to incentive situations, is that there is often very little legislative basis for incentive programs. This leaves the courts with little authoritative indication of how the program is to operate and what the policy for a program might be. As a result, administrators are left with great operational latitude as long as they do not treat unauthoritative guidelines as binding. In moderation, administrative flexibility is a valuable and necessary characteristic of the modern administrative state. However, vague and minimalist legislative structuring can result in officials straying beyond program mandates. ${ }^{104}$ At the same time, the ability of affected persons to challenge programs as unreasonable is diminished considerably when there is little indication in legislation of the policy or criteria upon which decisions are to be made. Hence, allegations of unreasonableness in the administration of many incentive programs may be difficult to prove, and legal accountability of administrators in this respect may be minimal.

\section{B. PROCEDURAL FAIRNESS IN INCENTIVE ADMINISTRATION}

Since the landmark Supreme Court of Canada decision of Nicholson v. HaldimandNorfolk Regional Board of Commissioners of Police, ${ }^{105}$ courts in Canada have signalled their intention to attach obligations of procedural faimess to government actions of an administrative nature in addition to the age-old requirement that the principles of natural justice apply to judicial and quasi-judicial activities of administration. The exact content of the procedural fairness obligations will vary with the circumstances. The primary remedy for breaches of fairness is certiorari, a remedy which can attach "to any public body with power to decide any matter affecting the rights, interests, property, privileges, or liberty of any person." 106

The nature and scope of procedural fairness as it applies to incentive administration is at this stage unclear. The few cases in which fairness in incentive administration has been considered have not been particularly promising. In Scarborough Community Legal Services v. $R .,{ }^{107}$ a case concerning registration for tax charitable status, ${ }^{108}$ the Federal Court of Appeal held 2:1 that no obligation was owed to an applicant organization to give it notice of a pending decision to refuse status, nor to provide it an opportunity to respond. The case hinged on the fact that appeals in certain circumstances were expressly provided for in the Income Tax Act. ${ }^{109}$ In Re Toronto Independent Dance Enterprise and Canada Council, ${ }^{110}$ the court held that procedures set up by the Council for notifying a dance company that their application for renewal of an annual grant would not be accepted were sufficient to meet the principles of procedural fairness. The dance company had been informed in advance of the recommendation to deny funding as they had been

For a recent discussion of this, see the Report of the Auditor General of Canada 1985, supra note 28, concerning the Industrial and Regional Development Program.

[1979] I S.C.R. 311.

Marrineau and Butters v. Matsqui Institution Disciplinan Board, [1978| 1 S.C.R. 118.

[1985] 2 FC 555 (Fed. C.A.) [hereinafter Scarborough].

The incentive created by charity status is for individuals to donate to charities, and for charities to perform services considered beneficial to society.

109

110 
supplied (upon request) with a copy of the assessor's report and been given the opportunity to explain to Board members (though not the Board itself) why the initial decision to reject should be reconsidered. Because of several distinguishing features in the TIDE case," it is difficult to predict at this point what precedent value the decision may have.

The act of providing a grant or incentive can be considered a type of benefit dispensing activity of government akin (although not identical) ${ }^{112}$ to public disbursements of licences or leases. Traditionally, courts have tended to view discretionary benefits as privileges, not rights. ${ }^{113}$ On this basis they have attached few useful procedural protections to their distribution. ${ }^{114}$ Recently, there has been some judicial movement away from such a stark in/out classification system ${ }^{115}$ but how this will be applied to incentives cannot be stated with certainty at this point. While bearing in mind the distinctions between incentives and other types of benefit-dispensing activities, a strong argument can be made that the same basic procedural protections should apply to all such activities. ${ }^{116}$

With licence dispensations, courts have indicated that administrators must let persons know what their impressions are concerning an application so that she or he can disabuse them of any incorrect information they might have. ${ }^{117} \mathrm{~A}$ basic set of reasons should be supplied, at least where requested by the applicant. ${ }^{118}$ Common sense suggests that a similar approach should be applied to incentive dispensations, so that, for example, the

Most notably, the fact that TIDE had already received annual grants in past years, and the independent status of the Canada Council.

Benefit dispensing activities of government need not have any overt incentive component. For example, many types of social assistance are not directly intended to change or influence behaviour. For significance of distinction between incentives and other types of benefit dispensations, see above at II "Definitions."

Sec, e.g., Scarborough, supra note 107 (registration for tax charitable status); Ghuman v. Minister of Transport et al., [1983] 2 Admin. L. R. 1 (licensing); Dowhopluk v. Martin (1972), I O.L.R. 311 (citizenship); compare with Singh and Minister of Employment and Immigration, [1985] I S.C.R. 177 (judgments of Wilson and Beetz JJ.) [hereinafter Singh].

Professor D. Mullan, in "Unfairness in Administrative Processes - The Impact of Nicholson and the Charter of Rights" in Justice C. Huband, Isaac Pitblado Lectures on Advocacy Rights and Remedies New Developments (Law Society of Manitoba: February, 1983) 68 at 77:

At this point, the old concept of "privilege" is still employed by some courts to defeat the procedural claims of those seeking government largesse. [footnotes omitted]

E.g., see judgment of Wilson J. in Singh, supra note 113.

Arguably, the same dynamics are at play regardless of whether there is an incentive component attached to a benefit i.e. persons' interests are directly affected by such programs and by individual decisions of administrators made pursuant to such programs. As a result, the same basic procedural protections should be afforded to applicants for all types of benefit dispensing activities. Indeed, the fact that incentives are intended to influence or change behaviour should be a point in favour of greater procedural protections being attached to incentives than other types of benefit dispensations.

See, e.g., R. v. Gaming Board for Great Britain. [1970] 2 Q.B. 417 (C.A.); and Griffin, supra note 89.

R. v. Lancashire County Council, [1986] 2 All E.R. 941. 
applicant knows in full the requirements he or she is to meet and has an opportunity to make representations that he or she meets the standards.

Another obstacle to effective accountability in incentive administration is the contractual nature ascribed to many government-recipient incentive arrangements. Until recently, courts have been reluctant to fully apply public law principles and doctrines to matters which resemble private, contractual arrangements. ${ }^{19}$ There can be no doubt that in many cases the process leading to and the consummation of incentive agreements includes basic contractual features: most notably, offer, acceptance and some form of consideration. Indeed, courts have on several occasions concluded that incentive agreements were contractual in nature. ${ }^{120}$ However, the points of distinction between incentive agreements and private contracts are also notable: the ability of legislatures to referentially incorporate whole regulations into the terms of agreements, ${ }^{121}$ to unilaterally overturn or derogate from agreement terms, ${ }^{122}$ the unusual technical requirements applying to administrators as agents of the Crown, ${ }^{123}$ the great disparity in bargaining capabilities between the parties, the fact that public policy objectives are being achieved and the indirect nature of the consideration (eg., with the exception of procurement contracts, there are no clear "goods and services" being received by government). ${ }^{124}$

One difficulty with the contractual characterization is that it signals a private business relationship between government and the recipient which tends to marginalize the public dimensions of the arrangement and in turn, to detract from the accountability of the incentive disbursement process. This manifests itself in a number of ways. Traditional notions of privity of contract imply confidentiality and a private arrangement between the two parties to the agreement, whereas in fact an incentive may be intended to benefit certain communities in the public interest. In contract law, the values of predictability and efficiency are of prime significance but in public law, concerns with openness, fairness and accountability in government decision-making take on special importance. ${ }^{125}$ In the past, courts have been reluctant to apply notions of procedural fairness to the buying and selling activities of the federal government. ${ }^{126}$ Although recent decisions ${ }^{127}$ indicate

See, e.g., Allard Contractors Ltd. v. District of Coquitlam et al., [1983] 3 Admin. L.R. 122.

E.g., Somerville Belkin Industries Limited v. Manitoba, [1988] 3 W.W.R. 523; Canada (A.G.) v. Newfield Seed Lid., [1989] 63 D.L.R. (4th) 644 [hereinafter Newfield]; I/16.92/6 Quebec Inc. v. Canada (27 October 1988), Judgment No. 941 (Federal Court Trial Division) and tentative contractual characterization in 251798 Ont. v. R., [1979] 106 D.L.R. (3d) 564.

See, e.g., discussion of this issue in Newfield, ibid.

On the general ability of legislative override of contractual or licensing terms, see also R. J. Harrison, "The Legal Character of Petroleum Licences" (1980) 58 Can Bar R. 483 at 484.

See, e.g., R. v. Transworld Shipping Lid. [1976] I F.C. 159; R. v. CAE Industries Lid. et al., [1985] 5 W.W.R. 481, and J.E. Verreault \& Fils Liee v. AG Que., [1977] I S.C.R. 41.

Instead, the "consideration" is apparently the achievement of public policy objectives.

See generally, Law Reform Commission of Canada, Independent Administrative Agencies, supra note 25, especially at 8-9. As was stated earlier, this is not to suggest that privatc contractual relationships lack any concern for fairness, but rather that the notions of procedural fairness as we know them in public law are less of a concem in contract law.

E.g., Allard Contractors, supra note 119.

See, e.g., Quasar Helicopters Ltd. v. R., [1985] 1 FC 536; Thomas C. Assaly, supra note 90. 
a new judicial willingness to apply fairness principles to federal procurement contracts for tender, it is unclear whether the logic apparent in these decisions will be applied to cover incentive contract disbursement, and if so, to what extent. ${ }^{128}$

The newly created federal Procurement Review Board, ${ }^{129}$ which reviews certain procurement contract awards for fairness and openness, is indicative of some political recognition of the need for third party review of administrative fairness and accountability even in commercial settings. However, there is no guarantee that legislators, administrators or courts will see fit to adopt a similar approach to incentive "contracts." Thus, while in the past the apparent contractual form of incentives may have been considered sufficient reason to deny incentives the same type of procedural protections we associate with traditional regulatory instruments such as licences, there are indications that even commercial activities of government are now attracting public law procedural protections. In light of these new developments, it is difficult to imagine on what basis an argument could be made that incentives are not deserving of similar scrutiny.

In general, courts seem more willing to attach protections where terminations or revocations are involved as compared with initial allocation decisions. One commentator has suggested that some sort of vesting of rights theory seems to be at play. ${ }^{130} \mathrm{In}$ effect, an expectation has been created through the actions or words of government officials, and courts seem willing to intervene when they perceive that the actions or words are being broken. The legal doctrine most clearly relevant to incentive withdrawals is "legitimate expectations." It is considered to be an elaboration of procedural fairness principles, ${ }^{131}$ and has been described as follows:

But even where a person claiming some benefit or privilege has no legal right to it, as a matter of private law, he may have a legitimate expectation of receiving the benefit or privilege, and, if so, the courts will protect his expectation by judicial review as a matter of public law....Legitimate, or reasonable, expectation may arise either from an express promise given on behalf of a public authority or from the existence of a regular practice which the claimant can reasonably expect to continue. ${ }^{132}$

While the general idea of an express promise or regular practice seems clear enough, application of these concepts may not be so straightforward. Courts have been careful to

The existence of the formalized bidding process with contracts for tender differs from the general applications process for many incentive programs. However, an incentive initiative such as the Federal Contractors Program, which involves an initial "certification" of commitment to implement employment equity, indicates how a regulatory "public policy" dimension can be grafted on to an otherwise commercial tendering process. Arguably, public law notions of procedural faimess should apply at least to those aspects of a tendering process which are regulatory in nature. Trade Agreement Implementation Act S.C., 1988, c. 65. 
note that the implementation of a promise must not interfere with a statutory duty. ${ }^{133}$ In incentive contexts, there may be statutory duties requiring that monies are only to be provided where persons meet the criteria, and where appropriations have been provided. ${ }^{134}$ There may be problems with the notion of "regular practice" as well. For example, just when does practice become "regular"?

In a number of cases concerning financial assistance, ${ }^{135}$ legitimate expectation-type arguments have been raised. Sometimes, they are specifically referred to as such, in others they are not. One of the most thorough treatments of the legitimate expectation issue in a financial assistance setting is the Ontario Court of Appeal decision $R e$ Webb and Ontario Housing Corporation, ${ }^{136}$ concerning termination of a subsidized housing tenancy. The Court held that once an individual becomes a tenant and thus qualifies for or receives a real benefit of reduced or subsidized rent, the Corporation must act fairly in deciding whether to terminate the lease. In the circumstances of the case, the Court determined that if the Corporation makes the tenant aware of the proposed termination and gives the tenant an opportunity to remedy the complaints and respond to them, then the interests of procedural fairness have been met. ${ }^{137}$

The fact situation under consideration in the Webb case was rather sympathetic to the tenant a welfare recipient who was statutorily entitled to social assistance and the termination of her lease to low-income housing. It could be maintained that in an incentive context, where an individual's personal welfare may not be directly at stake, courts would be less inclined to attach any significant duties of procedural fairness. However, arguably the same principles are at play. As one senior federal official put it, "the decision not to provide further support [pursuant to a financial incentive program] is extremely difficult when this is tantamount to cutting off life support..." ${ }^{\text {138 }}$ Given the fact that incentive programs are designed to influence or alter behaviour in some respects a more intrusive activity than providing social assistance to persons in need a strong argument can be made that they are deserving of procedural obligations ensuring fairness at least as onerous as those applying to financial assistance administration.

Courts have indicated a willingness to impose fairness obligations on individual termination situations in certain contexts. In Renaissance International v. $M N R,{ }^{139}$ the Federal Court of Appeal was considering a decision by the Minister of National Revenue official to revoke charitable status under the Income Tax Act. The appellant had not been made aware of the allegations against it, nor the fact that investigations were even being made. Furthermore, the appellant had not been given the opportunity to present its side.

Supra note 131.

Supra, note 34.

Cf. the distinction between financial assistance and financial incentives. As to the applicability of these cases to incentive situations, see discussion below at $\mathrm{V}$ "The Charter and Incentive Administration".

(1979), 93 D.L.R. (3d) 187 [hereinafter Webb].

Ibid. at 195.

Supra note 16 at 42 . While Ritchie was apparently speaking about terminations of entire programs, arguably the same logic would apply to individual denials of funds.

[1983] 1 F.C. 860. 
The Court held that the appellant's rights had been seriously and adversely affected, and that the appellant must be given a reasonable opportunity to answer to allegations made against it. The pivotal point in the Court's reasoning appears to be the fact that, pursuant to the Income Tax Act, decisions to revoke were appealable to the Federal Court. ${ }^{140}$ The existence of this right of appeal seemed to result in a characterization of the original decision to revoke as judicial or "quasi-judicial" in nature. ${ }^{141}$ Because the Court would normally decide an appeal on the sole basis of the record constituted by the original decision-maker, it was important that there be created by the administrators a record sufficiently complete to indicate the positions of the two disputing parties. This would require that the Minister adopt a procedure enabling preparation of a record reflecting not only his point of view but also that of the organization concerned. No mention is made in the decision of "legitimate expectations," but the approach taken is consistent with its tenets. Once again, it can be seen that the existence of an elaborated statutory regime setting out administrative procedures assisted the courts in reaching a conclusion which would enhance the accountability of administrators in their decision-making.

Probably the most ambitious attempt to incorporate a claim of legitimate expectations in a financial incentives setting is Toronto Independent Dance Enterprise v. Canada Council, a case which was discussed earlier. ${ }^{142}$ The plaintiff organization argued inter alia that, as a result of receiving project grants for a number of years, it had a legitimate expectation in receiving this benefit. It was contended that the plaintiff "had become financially dependent upon the grants, to the point of reliance." 143 As a result, the plaintiff proposed that an opportunity to make submissions before the decision to terminate the funding was necessary following the reasoning in Webb. ${ }^{144}$

The Federal Court Trial Division dismissed the plaintiff's applications. Rouleau J., speaking for the Court, characterized the grant as a benefit for which an applicant must qualify annually, with no right thereto created under the Act. ${ }^{145}$ The Webb case was distinguished on the basis that the provision of low-income tenancy was an "ancillary right" of the statutory entitlement to social assistance. Hence deprivations of that ancillary right necessitated certain obligations of procedural fairness. ${ }^{146}$ In light of this and other factors (eg., the independence of the Council, the large volume of applicants and the fact that the Council had developed its own procedures and guidelines), the court concluded that Council's actions in responding to the plaintiff's concerns were sufficient to meet the demands of procedural fairness.

The impression left upon reading Rouleau J.'s decision is that either the legitimate expectation doctrine does not apply to TIDE's situation, or if it does, only to a lesser extent than terminations of ancillary entitlement programs such as in Webb. A more

S. 172(3) of the Income Tax Act, supra note 30.

Per Heald J. supra note 139 at 868.

Supra note 110.

Ibid. at 508.

Ibid.

Ibid. at 510.

lbid. at 510-511. 
common sense distinction between TIDE and Webb is that Webb involved a curtailment of an already agreed upon and disbursed benefit (i.e., a lease) whereas in $T I D E$, the plaintiff was not having its allocated benefit terminated. Rather, the dance company was applying for a new annual grant, and was informed in advance that recommendations were being made which would deny this funding.

This is not to suggest that the plaintiff in TIDE had no legitimate expectation to further funding; however, the grounds were different. Arguably, procedural protections should be afforded to a refusal to renew annual incentives even if this does not amount to a Webb termination situation because disbursement of a grant in earlier years is incontrovertible evidence that the applicant has in the past been seen to have qualified for the incentive. While this does not and should not mean that a person is "entitled" to subsequent annual incentives, it does support the need for explanations as to why that person does not now qualify, and an opportunity for that person to respond to these explanations (i.e., greater procedural obligations are owed to such applicants).

In the final analysis, Rouleau J., in TIDE approves of the procedural treatment which the plaintiff dance company received. The procedures adopted by Canada Council in relation to the plaintiff were significant: advance notice of a pending recommendation to deny funding, disclosure of the negative assessments upon which such recommendations were made and a subsequent opportunity to explain to members of the Board why their decision was incorrect. Although these were not considered sufficient procedural protections in the eyes of the plaintiff dance company, they nevertheless would appear to go a substantial way toward ensuring that applicants have an opportunity to know the case against them and to make submissions thereupon. Through such a regime, in most circumstances administrators can be held accountable for their decisions. In this sense, the type of procedures adopted by Canada Council, if formalized and binding, could provide a model for other departments and agencies.

The contractual form of many incentive agreements may lead some courts to conclude that less notice and comment obligations are necessary for the termination of incentives than for curtailment of regulatory permissions such as licenses. To counteract this line of reasoning, incentive recipients who are faced with the prospect of termination may be able to use the fact that third party interests will be adversely affected as grounds for a more thorough and formal hearing than would otherwise be forthcoming. In Re Prysiazniuk, ${ }^{147}$ the Court characterized a contract between the regional municipality and the applicant lodging home for needy persons as in the nature of a licensing arrangement. ${ }^{148}$ Thus, when the Commissioner of Social Services for the region terminated the contract for contraventions of the fire code, the court held that such a decision effectively deprived the applicant of its livelihood and seriously threatened the well-being of the residents, so that such terminations could only take place in accordance with the principles of procedural fairness. ${ }^{149}$ In the circumstances of the case, this entailed providing the applicant with a clear statement of the concerns of the respondent, a reasonable time to meet those 
concerns and a reasonable opportunity to respond to any allegations. ${ }^{150}$ While the contract in Prysiazniuk was not in the nature of an incentive, the reasoning would arguably be applicable to many incentives where third party interests are affected by termination actions.

\section{THE CHARTER AND INCENTIVE ADMINISTRATION}

The Charter embodies legal principles which, if rigorously applied to incentive administration, could strengthen the ability of individuals to hold officials accountable for their actions and decisions. In many ways, the key principles involved are closely related to the common law doctrines which were discussed above. In Singh, ${ }^{\mid 51}$ Wilson J. concluded that the $\mathbf{s} .7$ concept of fundamental justice included at least the notion of procedural fairness. ${ }^{152}$

Early decisions confirm that the Charter applies to virtually all aspects of government activity, including Cabinet decisions. ${ }^{153}$ It would appear then, that contracting activity of the federal government would be reviewable for compatibility with Charter principles, although to what extent is not clear at this point. ${ }^{154}$

In order to successfully invoke s. 7 and its requirement that the principles of fundamental justice be met, it must first be demonstrated that there has been or is potentially a deprivation of life, liberty, or security of the person. ${ }^{155}$ The phrase "life, liberty, or security of the person" has been interpreted to refer to the physical and mental well-being of natural persons, and not purely economic interests. ${ }^{156}$ The fact that any Charter challenge pertaining to government acts or decisions concerning financial incentives would clearly involve economic interests does not detract from the reality that in many cases the "life, liberty, or security" of persons could also be affected. For example, an incentive to encourage pollution abatement, if not enforced, could affect the security of persons in the community. The Supreme Court of Canada has signalled its intention to interpret Charter provisions broadly and generously. ${ }^{157}$ In keeping with this general approach, Wilson J. has indicated that the traditional distinction between rights

Ibid.

Supra note 113.

Wilson J. referred with approval to the discussion of procedural fairness by Fauteux J., in Duke v. R., [1972] S.C.R. 917 at 923.

Operation Dismantle Inc. et al. v. The Queen et al. (1985), 13 C.R.R. 287.

For early discussion of this point, see K. Swinton, "Application of the Canadian Charter of Rights and Freedoms" in W.S. Tarnopolsky \& G.A. Beaudoin, supra note 91 at 49, where she urges the development of a "governmental function" test to decide which activitics should be subject to the Charter. The difficulty is determining when an incentive function is "commercial", and when it is governmental, given the grafting of public policy objectives on what would otherwise appear to be commercial relationships.

In Operation Dismantle, supra note 153, the Supreme Court of Canada held that there must be a clear causal link between the impugned state action and the deprivation in question: mere speculation is not enough.

See, e.g., Tarnopolsky JA, speaking for the Ontario Court of Appeal in R. v. Videoflicks Lid. et al. (1984), 15 CCC (3d) 353 at 391, and Irwin Toy Ltd. v. Quebec (AG), [1989] I S.C.R. 927.

R. v. Big M Drug Mart Lid., [1985] I S.C.R. 295. 
and privileges (discussed earlier) has no place in Charter s. 7 analysis. ${ }^{158}$ Thus, the stage has been set for $\mathrm{s} .7$ application to incentive contexts.

The second major Charter provision of potential relevance to incentive activity is s. 15, and its stipulation that every individual "is equal before and under the law and has the right to the equal protection and equal benefit of the law without discrimination...." (emphasis added). ${ }^{159}$ The proposition that laws, policies, rules, etc. can in practice have an adverse discriminatory effect, even though this might not have been intended, is now well accepted, and is known as "systemic discrimination."160 Incentive programs currently in operation are susceptible to challenge on grounds that in practice they operate in a manner which is discriminatory to certain groups. At the time of writing this article, a coalition of groups was challenging a program providing funds for official language training of immigrants on the basis that in fact the program discriminated against women and in favour of men. ${ }^{161}$

Incentive programs could also be challenged through the use of other Charter provisions. For example, an incentive program which requires that recipients publish brochures or advertise in certain languages, or restricts what can be said in brochures or signs could be attacked as contrary to the fundamental freedoms of communication and expression set out in $\mathrm{s} .2$ of the Charter. ${ }^{162}$

It is also possible that government may be compelled to establish incentive programs in order to meet its Charter obligations. For example, where a department does not provide funds to allow disadvantaged and potentially adversely affected groups to meaningfully comment on a proposed regulatory initiative, it might be susceptible to challenge under a combination of s. 7 and s. 15 (i.e., deprivation of life, liberty and security of person and discriminatory effect of a current initiative). In effect, departments and agencies may be under a Charter obligation to create special initiatives which will encourage disadvantaged groups to voice their comments about government initiatives which may affect them.

In short, Charter provisions can potentially be used by individuals and groups to challenge terms and administration of incentive programs, and perhaps in certain cases to force creation of new incentive initiatives. As such, Charter principles are an important adjunct to traditional common law approaches as a means of holding government officials accountable for their decisions and actions concerning incentive programs. As a result, government departments and agencies would be well advised to design and implement their programs in a way which reflects Charter values.

Singh, supra note 113.

Supra note 6 at s. 15.

See, e.g., discussion in Law Reform Commission of Canada, Policy Implementation, Compliance and Administrative Law (Working Paper 51) (Ottawa: Law Reform Commission of Canada, 1986) at 27.

N. Doherty, "Immigrant women's organization joins challenge of language training program" LEAF Lines (April 1990) at 4-5.

For a similar type of action in the United States, see Rust et al. v. Sullivan 500 US, 114 L Ed 2d 233, 111 S Ct 1759 (1991). 


\section{THIRD PARTIES IN ENFORCEMENT - UNEXPLORED TERRITORY}

As was mentioned earlier, a significant distinction between incentive arrangements and traditional regulatory instruments is typically the low recognition of the role third parties can play in incentive administration and enforcement. That there should be greater recognition of this role might seem obvious from an examination of the intended beneficiaries of many incentive programs. For example, with the Employment Equity Federal Contractors Program, the position of minorities and disadvantaged persons in the workplace is to be improved by agreements between government and employers. ${ }^{163}$ Hence, formal procedures to ensure their input in administration and enforcement would appear to be well advised. Similarly, a loan or contribution to a smelter for pollution abatement equipment improvements is presumably intended to ensure that at least the local community is protected from environmentally harmful consequences of smelter operations. Loan or contribution agreements could include provisions stipulating that affected communities are formally consulted and can participate in monitoring implementation and ensuring that commitments are kept.

With many traditional regulatory instruments, third parties can at least participate in enforcement decisions through the route of private prosecutions. ${ }^{164}$ In effect, this is an accountability mechanism helping to ensure that, for example, terms of pollution abatement permits are enforced. Just as administrators might not enforce the terms of traditional regulatory instruments in a manner considered acceptable by affected parties (thus necessitating a private prosecution), the same scenario could play out with respect to incentive implementation. The likelihood of government officials turning a blind eye on breaches of incentive agreements is not mere speculation. Reports of departments disbursing funds before demonstrated need, ${ }^{165}$ providing incentives to projects not fitting within eligibility criteria ${ }^{166}$ and failing to enforce contract terms ${ }^{167}$ are not uncommon.

However, with discretionary incentive programs, problems of standing, lack of mandatory language compelling administrators to enforce and the contractual characterization present formidable legal barriers to third party involvement. The Finlay ${ }^{168}$ case stands for the proposition that third parties may in certain circumstances be granted the standing to bring actions in the public interest for declaratory relief where governments are not abiding by legislative arrangements of a financial nature. The Finlay

E.g., intended beneficiaries of employment equily initiatives are implicated in administration of the Federal Contractors Program when unions and management agree on a hiring policy regarding physically disabled persons but do not consult with local groups representing those interests, and do not provide an official mechanism for beneficiaries to ensure that contractual obligations are met. Other possible techniques include a complaint procedure where the Minister is obligated to investigate any complaint received and supply a report to the complaining party (this is provided for in some legislation, such as ss. 108 - 110 of the Canadian Environmental Protection Act, S.C. 1988, c. 22), and appointment to monitoring and management committees associated with an incentive. E.g., see Minutes of House of Commons Standing Committee on Public Accounts, in Debates, (9 Dec 1982) at 66:11. 
decision dealt with the federal government continuing to provide payments under the Canada Assistance Plan (CAP) in spite of the fact that the province of Manitoba was not meeting the terms of the Plan. But there are at least two distinguishing features to the Finlay fact situation which aided the Court in its decision to award standing to the plaintiff, and which are unlikely to be replicated in the majority of incentive contexts. First, there was an explicit requirement in $C A P$ that the federal government disburse funds to the provinces only if the undertakings in the agreements were observed. ${ }^{169}$ With respect to incentive programs, there may be no explicit statutory stipulation that funds should only be disbursed upon conditions being met; instead, funds are merely "recoverable" in such circumstances, denoting a discretionary decision.

A second distinctive feature of the Finlay case was the fact that CAP explicitly contemplated and defined the beneficiary of the program as a "person in need." Thus, the ability of the welfare recipient Finlay to establish his "genuine interest" was greatly enhanced. The same could not be said with respect to many incentive programs, where the beneficiary/affected interest may only be implied. A sympathetic judge in the right set of circumstances should be able to perceive the genuine interest of affected third parties in seeing that terms of incentive agreements are followed but there is no guarantee of this.

The second obstacle to effective third party involvement is (once more) the contractual characterization of many incentive agreements. In the United States, the "third party beneficiary rule" has been developed by the courts which acknowledges the existence of affected third parties in contractual contexts, and allows them to enforce the contract in certain circumstances. ${ }^{170}$ In Canada, such a rule does not exist, and there is generally no recognition of a role for such parties. The Prysiazniuk case (discussed earlier) suggests that in certain circumstances, courts may be prepared to recognize the existence of third party beneficiaries in a government contract situation and provide special rules where their interests would be detrimentally affected by a withdrawal. Nevertheless, there is an enormous gap between recognizing that third parties may be affected and empowering them to initiate an action for enforcement. There is nothing preventing administrators from drawing up contracts with provisions which explicitly allow for third party participation (e.g., in monitoring and enforcement).

\section{CONCLUSIONS}

Financial incentives are powerful and pervasive governing instruments which are used to encourage or alter certain behaviours in furtherance of public policies. They have significant impacts on individuals, organizations, corporations and communities. Incentives offer a number of advantages over traditional regulatory instruments: they may be effective at inducing changes of behaviour where threats and penalties are not appropriate. They operate in a consensual rather than a coercive manner. In some respects, they may be less expensive to operate than traditional instruments. In the interests of greater legal accountability, it has been suggested here that incentives should be subject to a legal

170 A.J. Waters, "The Property in the Promise: A Study of the Third Party Beneficiary Rule" (1985) 98 Harv. L. Rev. 1111. 
structure similar to that associated with traditional regulatory instruments. This would entail putting legal constraints on the ability of the federal government to indirectly regulate matters of provincial jurisdiction, more fully elaborating the terms of incentive programs in legislation and regulations, providing for notice and comment of draft program terms, applying procedural fairness principles to disbursement and enforcement decisions and putting in place rules which will enhance the likelihood for meaningful third party participation to take place.

These reforms are suggested without denying the significant differences which exist between traditional regulatory instruments and incentives. Nevertheless, the functional analysis undertaken in this article suggests that in the reality of modern governing, the more subtle methods of affecting behaviour in furtherance of public policy objectives should not escape thorough structuring simply because they may not involve overt coercion or obvious deprivations of liberty, security, or property. The reality is that through use of its financial powers, government has direct and indirect control over the quality of life of many individuals and the communities in which they live. Governments may not be obliged to establish incentive programs, but when such programs are contemplated or put into place, there must be sufficient legal framework to ensure accountability.

In this regard, it is inappropriate to wait for courts to articulate a full legal structure. Still, the general tenor of court decisions to date does provide guidance as to how legislators and administrators should approach legal structuring. For example, while the courts have made formal distinctions between "compulsory" legislation and "voluntary" incentives, they have cautioned against federal legislation which encroaches upon the provincial field through indirect means. Federal-provincial agreements outlining on what terms federal spending programs may be allowed to operate in provincial jurisdictions should be negotiated.

While not enthusiastically supporting the practice, the courts have stated that incentive programs can be authorized by nothing more than a vote in an Appropriation Act. But in the interests of providing Members of Parliament with adequate detail to make informed decisions, and in the interests of providing administrators, affected persons and the courts with guidance as to how incentives are to operate, such initiatives could be more fully articulated in legislation. As well, instead of informal and perhaps even unwritten directives concerning incentive operation, regulations should set out these terms so far as is practicable. In turn, draft regulations for incentive programs should be included in the Regulatory Plan and Canada Gazette Part I prior to formal promulgation. Where use of statutory instruments is not feasible, procedures could be established which require that draft and final terms of programs not promulgated by regulation or order in council are made available to affected individuals, organizations and communities for their comments.

With judicial acceptance of the idea that procedural fairness principles apply to administrative acts, and that certiorari lies where a person's interests are affected, the courts have given a clear signal that bureaucratic decisions with respect to incentive disbursement and administration should be structured and that officials will be held accountable. Extrapolating from existing court decisions, it would appear that at the very 
least, applicants should be entitled to know what rules are being applied to their case and be given an opportunity to persuade officials of how and why their application is deserving of funding. Similarly, in cases of withdrawals and terminations, the recipient should be apprised of pending action and given an opportunity to respond. Reasons for negative decisions should be supplied on request.

The fact that many incentive agreements have been characterized as contracts is problematic: it may imply that the administrative process for disbursement and administration is akin to a private, bilateral and commercial relationship, and not amenable to public law notions of fairness or public participation. While courts have begun to look past the contractual characterization, to attach fairness obligations to public contract administration and even to recognize that third party interests are affected, legislators and administrators could facilitate this development considerably by setting out the procedures which administrators are to follow (e.g., requiring that administrators establish a complaints procedure), and by specifying the role that third parties are to play (e.g., appointment of citizens to disbursement committees, monitoring committees, and providing for specific "rights" for citizens to enforce contracts).

Although it cannot be denied that courts are the ultimate arbiters of legal accountability, the problems which the judiciary has had with reviewing aspects of financial incentive administration perhaps indicate the need for creation of other institutions to turn to when problems arise -... bodies less formal and legalistic than the courts such as administrative tribunals and ombudspersons. The experience of the federal Procurement Review Board and English Parliamentary Commissioner for Administration are examples which could be emulated (with modifications) to apply to incentive administration. The advantages of recourse to review boards and ombudspersons appear to be obvious: informal solutions could be reached without the expense and even paralysis which can occur when persons are compelled to resort to the courts for relief.

It seems evident that government's fingers, like its thumbs, need significant structuring to ensure accountability. Whether a loosely knit mitten or a snugly fitting glove is woven is largely in the "hands" of legislators and administrators. It seems evident that these two actors should take the initiative, and not let the courts gradually knit some strange mitten/glove hybrid, one finger at a time. 